\title{
RISK FACTORS AFFECTING HEARING IN NEONATAL INTENSIVE CARE UNIT NEONATES
}

\section{Emmanouil Nisotakis, Vasilios Chalkiadakis, Pavlos Marangoudakis, Antonios Tzagkaroulakis, Thomas Nikolopoulos}

\author{
$2^{\text {nd }}$ University ENT Department, Attiko University Hospital, Athens, Greece
}

Corresponding author: Emmanouil Nisotakis, 8 Paparigopoulou Str, Agia Paraskevi, Athens, Greece, PO 15343, e-mail: nisotakis@hotmail.com

\begin{abstract}
Background: Neonatal intensive care unit graduates are considered to be of higher risk for hearing impairment, either auditory neuropathy or hearing loss. In this study we examine the presence of risk factors and try to identify their effect on the hearing of high-risk neonates.
\end{abstract}

\begin{abstract}
Material and methods: In this prospective cohort study we used automated auditory brainstem responses (a-ABRs) and otoacoustic emissions (OAEs) to screen 453 neonatal intensive care unit neonates who had at least one risk factor for hearing impairment.
\end{abstract}

Results: In the initial examination, $382(84.3 \%)$ infants passed and 71 (15.7\%) failed a-ABRs. Out of those who failed, 39 newborns (55\%) passed the transiently evoked otoacoustic emission (TEOAE) test, while 32 (45\%) failed that test too. Re-examination was performed before their first month of age, eventually resulting in 8 newborns being diagnosed with possible hearing loss and 8 with possible auditory neuropathy. The overall dropout rate was $4.9 \%$. Low birth-weight $(p=0.016)$, as well as craniofacial abnormalities $(p=0.03)$ and TORCH (toxoplasmosis, rubella, cytomegalovirus, herpes) infections proved to have a statistically significant correlation $(p=0.05)$ with hearing impairment.

Conclusion: Because a significant number of children may have auditory neuropathy, ABRs and OAEs (both transiently evoked and distortion product OAEs) remain the cornerstones of any universal hearing screening program in neonatal intensive care units. An efficient tracking system is needed to reduce the number of neonates lost to follow-up. Low birth-weight, craniofacial deformities, and congenital infections appear to be the most significant factors predisposing an infant to hearing impairment.

Key words: neonatal hearing screening $\bullet$ auditory neuropathy $\bullet$ congenital hearing loss

\section{FACTORES DE RIESGO DE PÉRDIDA AUDITIVA EN LOS RECIÉN NACIDOS PERMANECIENTES EN LAS UNIDADES DE CUIDADOS INTENSIVOS}

\section{Resumen}

Introducción: Los recién nacidos dados de alta de las unidades de cuidados intensivos pertenecen al grupo de mayor riesgo de sufrir pérdida auditiva como la neuropatía auditiva o la reducción del umbral de audición. En este trabajo se ha estudiado la presencia de los factores de riesgo y se ha intentado señalar su impacto en el oído de los recién nacidos del grupo de alto riesgo.

Material y métodos: El estudio de cohorte prospectivo que aquí presentamos ha tenido el carácter de detección y ha incluido a 453 recién nacidos de la unidad UCI, en los que se había identificado al menos un factor de riesgo de pérdida auditiva. En este estudio se ha aplicado la prueba automática de potenciales del tronco cerebral (a-ABR) y la prueba de emisiones otoacústicas (OAE).

Resultados: En la etapa inicial de la evaluación, por 382 recién nacidos $(84,3 \%)$ se ha obtenido el resultado correcto, y en los $71(15,7 \%)$ - el resultado incorrecto de la prueba a-ABR. En el grupo de los bebés con resultado incorrecto, la prueba de la emisión otoacústica provocada por el ruido (TEOAE) ha dado un resultado correcto en 39 recién nacidos (55\%) e incorrecto en 32 (45\%). El nuevo examen se hizo antes de que los bebés terminaran 1 mes. En resultado de esta prueba, en 8 niños se sospechó la pérdida de audición, y en otros 8 bebés se diagnosticó la neuropatía auditiva. Un 4,9\% de los bebés no se han presentado a la nueva prueba.

Los defectos auditivos estaban correlacionados con el bajo peso al nacer $(p=0.016)$, anomalías cráneofaciales $(p=0.03)$ y las infecciones del grupo TORCH (toxoplasmosis, rubeola, citomegalovirus y herpes). 
Conclusiones: Debido al gran número de casos de detección temprana del riesgo de neuropatía, las pruebas ABR y OAE (tanto de la emisión otoacústica provocada por el ruido, como y de la emisión otoacústica de los productos de distorsiones) constituyen la base para el cribado auditivo general en las unidades de cuidados intensos neonatales. Para reducir el número de recién nacidos no sometidos a la segunda prueba, se debe desarrollar un sistema funcional y eficaz de contacto y comunicación con los pacientes. Como los factores de riesgo más importantes para la pérdida auditiva en los recién nacidos se enumera: bajo peso al nacer, anomalías en la zona craneofacial y las infecciones congénitas.

Palabras clave: cribado neonatal • neuropatía auditiva • defectos de audición congénitos

\section{ФАКТОРЫ РИСКА НАРУШЕНИЯ СЛУХА У НОВОРОЖДЕННЫХ, ПРЕБЫВАЮЩИХ В ОТДЕЛЕНИЯХ ИНТЕНСИВНОЙ ТЕРАПИИ}

\section{Изложение}

Введение: Новорожденные, покидающие отделения интенсивной терапии, принадлежат к группе повышенного риска развития нарушений слуха в виде слуховой нейропатии или снижения порога слышания. В настоящей работе исследуется наличие факторов риска и предпринимается попытка показать их влияние на слух новорожденных детей из группы высокого риска.

Материал и методы: Представленное проспективное когортное исследование имело скрининговый характер и включало 453 новорожденных из отделения интенсивной терапии, у которых был указан по крайней мере один фактор риска появления нарушения слуха. Использовано исследование стволомозговых потенциалов (a-ABR) и исследование отоакустических эмиссий (OAE).

Результаты: на начальной стадии оценки, у 382 (84.3\%) новорожденных был получен правильный результат, а у 71 (15,7\%) - неправильный результат в а-ABR. Среди этих детей, у которых обнаружен неправильный результат, исследование отоакустической, вызванной шумом, эмисси (ТЕОАЕ) показало правильный результат у 39 (55\%) новорожденных, а неправильный у 32 (45\%). Повторное исследование проводилось, прежде чем детям исполнился месяц. В результате у 8 детей появилось подозрение на нарушение слуха, а у следующих 8 был поставлен диагноз слуховой нейропатии. 4,9\% детей не появилось на следующем исследовании. С нарушениями слуха соотносился низкий вес при рождении $(p=0,016)$, деформация лицевого черепа $(p=0,03)$, а также инфекции из группы TORCH (токсоплазмоз, краснуха, цитомегаловирус и герпес) $(p=0,05)$.

Выводы: Ввиду значительного количества случаев раннее обнаруженного риска нейропатии, исследования ABR i OAE (как отоакустической эмиссии, вызванной шумом, так и отоакустической эмисси продуктов искажениz) являются базисом всеобщих скрининговых исследований слуха в отделениях интенсивной терапии новорожденных. С целью снижения числа новорожденных, не принимающих участия в поновном исследовании, следует разработать четкую систему общения и коммуникации с пациентами. Важнейшими факторами риска нарушений слуха у новорожденных детей считаются: низий вес при рождении, деформации лицевого черепа и врожденные инфекции.

Ключевые слова: скрининговые исследования у новорожденных • слуховая нейропатия • врожденные нарушения слуха

\section{CZYNNIKI RYZYKA USZKODZEŃ SŁUCHU U NOWORODKÓW PRZEBYWAJĄCYCH NA ODDZIAŁACH INTENSYWNEJ TERAPII}

\section{Streszczenie}

Wprowadzenie: Noworodki opuszczające oddziały intensywnej terapii zalicza się do grupy podwyższonego ryzyka wystąpienia wad słuchu w postaci neuropatii słuchowej lub obniżenia progu słyszenia. W niniejszej pracy zbadano występowanie czynników ryzyka oraz podjęto próbę wskazania ich wpływu na słuch noworodków z grupy wysokiego ryzyka.

Materiał i metoda: Przedstawione prospektywne badanie kohortowe miało charakter przesiewowy i obejmowało 453 noworodków z oddziału intensywnej terapii, u których wskazano co najmniej jeden czynnik ryzyka wystąpienia wady słuchu. Wykorzystano w nim automatyczne badanie potencjałów pnia mózgu (a-ABR) oraz badanie emisji otoakustycznych (OAE).

Wyniki: W początkowym etapie oceny, dla 382 (84.3\%) noworodków z nich uzyskano wynik prawidłowy, a 71 (1,7\%) - wynik nieprawidłowy w a-ABR. Spośród tych dzieci, u których stwierdzono wynik nieprawidłowy, badanie emisji otoakustycznej wywołanej trzaskiem (TEOAE) dało wynik prawidłowy u 39 noworodków (55\%), natomiast nieprawidłowy u 32 (45\%). 
Ponowne badanie wykonano, nim dzieci ukończyły miesiąc. W rezultacie u 8 dzieci wystąpiło podejrzenie wady słuchu, a u dodatkowych 8 zdiagnozowano neuropatię słuchową. 4,9\% dzieci nie zgłosiło się na ponowne badanie. $\mathrm{Z}$ wadami słuchu korelowała niska waga urodzeniowa $(p=0,016)$, anomalie twarzoczaszki $(p=0,03)$ oraz infekcje z grupy TORCH (toksoplazmoza, różyczka, cytomegalia i opryszczka) $(p=0,05)$.

Wnioski: Ze względu na znaczną liczbę przypadków wykrytego wcześnie ryzyka neuropatii, badania ABR i OAE (zarówno emisji otoakustycznej wywołanej trzaskiem, jak i emisji otoakustycznej produktów zniekształceń) stanowią podstawę powszechnych przesiewowych badań słuchu w oddziałach intensywnej terapii noworodków. Aby zmniejszyć liczbę noworodków nie poddanych ponownemu badaniu należy wypracować sprawny system kontaktu i komunikacji z pacjentami. Za najważniejsze czynniki ryzyka wad słuchu u niemowląt przyjmuje się: niską masę urodzeniową, anomalie w obrębie twarzoczaszki oraz zakażenia wrodzone.

Słowa kluczowe: badania przesiewowe u noworodków • neuropatia słuchowa • wrodzone wady słuchu

\section{Background}

Significant congenital hearing impairment has been shown to be one of the most frequent sensory birth defects, affecting 1 to 3 healthy neonates in every 1000 live births. Audiological risk factors have a 10 - to 20 -fold higher incidence, meaning that $2-5 \%$ of all newborns in neonatal intensive care units (NICUs) may be affected [1]. Since the development of fluent language depends on a high quality auditory signal, the severity of hearing impairment during critical periods of speech development in early life controls whether the acquisition of spoken language will be more or less severely compromised [2].

Language plays a key role in a child's effort to communicate and socially interact, thus it is crucial that any underlying hearing disorder affecting speech is identified as early as possible. Therefore, the Joint Committee on Infant Hearing (JCIH) strongly recommends all neonates should undergo hearing screening test by the first month of life and diagnosis should be made by 3 months of age, so that specialists can start treatment and intervention by 6 months [3]. Children diagnosed early by universal newborn hearing screening (UNHS) programs can benefit from the timely fitting of hearing aids or cochlear implants $[4,5]$. In this way, the detrimental consequences of linguistic deprivation can be avoided, and hearingimpaired children have the opportunity to grow up with normal developmental index scores, both in terms of academic and socioeconomic progress as well as emotional and psychological integrity [6].

The introduction of electro-acoustical tests, notably otoacoustic emissions (OAEs) and automated auditory brainstem responses (a-ABRs), is regarded as the cornerstone of UNHS programs. The JCIH has set separate test protocols for NICUs and well-infant nurseries, recommending a two-step screening procedure for all healthy low-risk newborns, with OAEs (transiently evoked or distortion product) followed by a-ABRs if there is no response at the original screening test. For NICU infants, who are at high-risk of developing retrocochlear hearing loss, JCIH recommends they should be examined with both tests at once to eliminate false negative results associated with auditory neuropathy spectrum disorders (ANSDs) [3]. First identified in 1996, auditory neuropathy is mainly a form of hearing impairment due to dyssynchronization of the cochlear/auditory nerve, while the outer hair cell function remains intact (as revealed by the presence of normal OAEs in contrast to the grossly abnormal or even absent ABRs) [7].

Congenital hearing loss is attributed in $30-50 \%$ of cases to perinatal environmental factors such as prematurity ( $<32$ weeks), low birth-weight $(<1500 \mathrm{~g})$, viral or bacterial infections (toxoplasmosis, rubella, cytomegalovirus, herpes; TORCH), severe birth asphyxia (Apgar Score $\leq 6$ at $5 \mathrm{~min}$ ), hyperbilirubinemia ( $>17 \mathrm{mg} / \mathrm{dL}$ ), exposure to ototoxic drugs (e.g. aminoglycosides), and need for mechanical ventilation ( $>5$ days). The remaining $50-70 \%$ is thought to be due to inherited genetic factors which result in either syndromic (30\%) or non-syndromic (70\%) profound hearing loss [8]. Over 400 syndromes presenting audiological disorders among other clinical manifestations have been identified, while almost 100 specific non-syndromic genetic loci inherited in an autosomal recessive, autosomal dominant, or X-Linked mode have been cloned [9]. Regarding non-syndromic deafness, it is more often related to mutations of genes that regulate the production of the gap junction protein connexin 26, which lead to abnormal cochlear hair cell function. Overall, only $50 \%$ of hearing impaired infants have known risk factors, a fact that underlines the necessity for UNHS [10]. Several studies have tried to identify and re-evaluate the role and relative importance of certain risk factors in the development of hearing loss $[11,12]$. The results of a preliminary study in the NICU of our hospital found a clear relation of TORCH infections and mechanical ventilation for over 5 days to the likelihood of hearing impairment [13].

In this study, we focus on the presence of audiological risk factors and try to clarify how they are linked to the development of congenital hearing loss, including ANSD, in the population of newborns hospitalized in the NICU of our tertiary hospital.

\section{Material and Methods}

Between 2012 and 2016, a total number of 619 neonates were admitted to the NICU of our hospital, and all of them were screened according to the recommendations of JCIH. In the present prospective cohort study, data from 453 neonates (73.2\%), admitted to the NICU for more than 24 hours with one or multiple risk factors, was analyzed. The hearing of all newborns was tested by automated ABRs (aABRs) in combination with transiently evoked otoacoustic emissions (TEOAEs). Individual newborn and maternal medical records were examined, while taking into 
consideration, according to the JCIH, the presence of any of the following hearing loss high-risk factors:

1. Family history of permanent childhood hearing loss;

2. Prematurity (<32 weeks);

3. Low birth weight $(<1500 \mathrm{~g})$;

4. Birth asphyxia (Apgar score $0-6$ at $5 \mathrm{~min}$ );

5. Assisted ventilation;

6. Medication ototoxicity (e.g. aminoglycosides, loop diuretics);

7. Hyperbilirubinaemia $(>17 \mathrm{mg} / \mathrm{dL})$ that required exchange transfusion;

8. In utero TORCH infection;

9. Craniofacial anomalies including those of the ear and temporal bone;

10.Presence of syndromes or physical findings clearly associated with syndromes which include hearing loss;

11.Early postnatal viral or bacterial infections associated with permanent hearing loss (e.g. meningitis);

12. Head trauma or intracranial hemorrhage;

13.Neurological disorders.

Prior to audiologic examination, families and caregivers were fully informed and gave their consent to proceed with the screening. A quiet examination room inside the NICU facility was used and the safety of newborns was reassured by the physical presence of a neonatologist throughout the test, although no emergency ever occurred. All tests were performed by the same specialized personnel using the same screening devices, and the results were noted down in both the newborn's medical record and a form designed for our study.

All neonates underwent otoscopic examination of the external ear canal and the tympanic membrane before hearing evaluation. TEOAEs and a-ABR tests were initially performed in both ears at least 48 hours after birth, usually following feeding so that the newborns would remain calm or fall asleep during the examination without being sedated. The recorded TEOAEs and a-ABRs were automatically checked and compared to normal patterns by the screening device, based on their reproducibility according to the manufacturer's standard settings. Normal presence of TEOAEs/a-ABRs was considered as PASS while absence as REFER. Newborns who failed the initial test were reexamined before their first month of age and if they still did not manage to pass the screening, they were referred to the audiology department for full hearing evaluation, the results of which are beyond the scope of the present study. Both the positive or negative results were disclosed to the parents or caregivers and explicit information about the follow-up procedure was provided.

A portable Madsen Accuscreen Pro OAE/ABR screener audiometer (Madsen, GN Otometrics) was used for all tests. For TEOAEs, the device produces clicks or tones at a level of 70-84 dB SPL and at frequencies ranging from 1.5 to $4.5 \mathrm{kHz}$; for a-ABRs, chirp stimuli of $30,35,40$, or $45 \mathrm{~dB}$ HL are applied. Prior to examination, the skin was cleaned with a non-alcohol agent and three electrodes were placed by means of adhesive pads with a hydrogel surface. The recording electrode was attached to the upper forehead, the reference electrode was placed on the mastoid process of the side examined at the time, and the ground electrode on the cheekbone. Soft probe ear tips of different sizes were available so that the probe would fit properly to the ear canal.

The Stata version 11 statistical software package (StataCorp LP, Texas, USA) was used for statistical analysis. Categorical variables comparison was performed with the Fisher Exact Test. Statistically significance was set at a $p$-value of 0.05 .

The present study conformed to the principles of the Declaration of Helsinki and was approved by the ethical committee of Attiko University Hospital where all medical investigation took place.

\section{Results}

In this study we enrolled 453 neonates, 267 (58\%) males and $186(42 \%)$ females, admitted to the NICU of Attiko University Hospital.

All neonates underwent a hearing screening test by use of a-ABRs, resulting in 382 infants passing on both ears and 71 failing the initial examination on at least one ear (PASS $=84.3 \%$, REFER $=15.7 \%$ ). Out of those who failed, 39 (55\%) passed the TEOAEs, while 32 (45\%) failed that test too. Re-examination included both TEOAEs and aABRs and was performed before their first month of age, but only 49 infants (69\%) presented in follow-up, whereas $22(31 \%)$ dropped out. Some 26 of the presenters had failed both TEOAEs and a-ABRs in the initial examination, while 23 had passed TEOAEs but failed in a-ABRs. Eventually, 33 of the presenters (67\%) passed both tests and were considered to have normal hearing, while 16 newborns (33\%) were diagnosed with hearing impairment. In the latter group, 8 infants (50\%) failed both TEOAEs and aABRs, 6 unilaterally and 2 bilaterally, and were diagnosed as having possible hearing loss (HL). The remaining 8 infants $(50 \%), 7$ of which had failed both TEOAEs and aABRs in the initial examination, after thorough cleaning of the ear canal eventually passed TEOAEs but failed aABRs again. Two of them failed a-ABRs unilaterally and 6 bilaterally, so they were considered to suffer from possible auditory neuropathy (ANSD), as depicted in Figure 1.

Regarding the overall population, the prevalence of possible ANSD, as well as possible HL, in our study was $1.8 \%$. Considering the infants who did not attend the re-examination, the overall dropout rate was $4.9 \%$. After the completion of the two-step protocol, the false REFER rate for TEOAEs was $4 \%$ whereas for a-ABRs it was $7.3 \%$.

Out of the 13 risk factors investigated, ototoxic medication appeared to be by far the most frequent one, present in 295 newborns (65.1\%). Prematurity was identified in 73 infants (16.1\%), assisted ventilation in 65 (14.3\%), low birth-weight $<1500 \mathrm{~g}$ in $64(14.1 \%)$, and hyperbilirubinemia in 54 (11.9\%). The rest of the risk factors appeared less frequently, while there was no case of a syndrome or congenital abnormality associated with hearing loss (Table 1). Co-existence of multiple risk factors was not infrequent, with the majority of newborns (48\%) presenting with two risk factors while there was no case of having more than seven (Figure 2). 


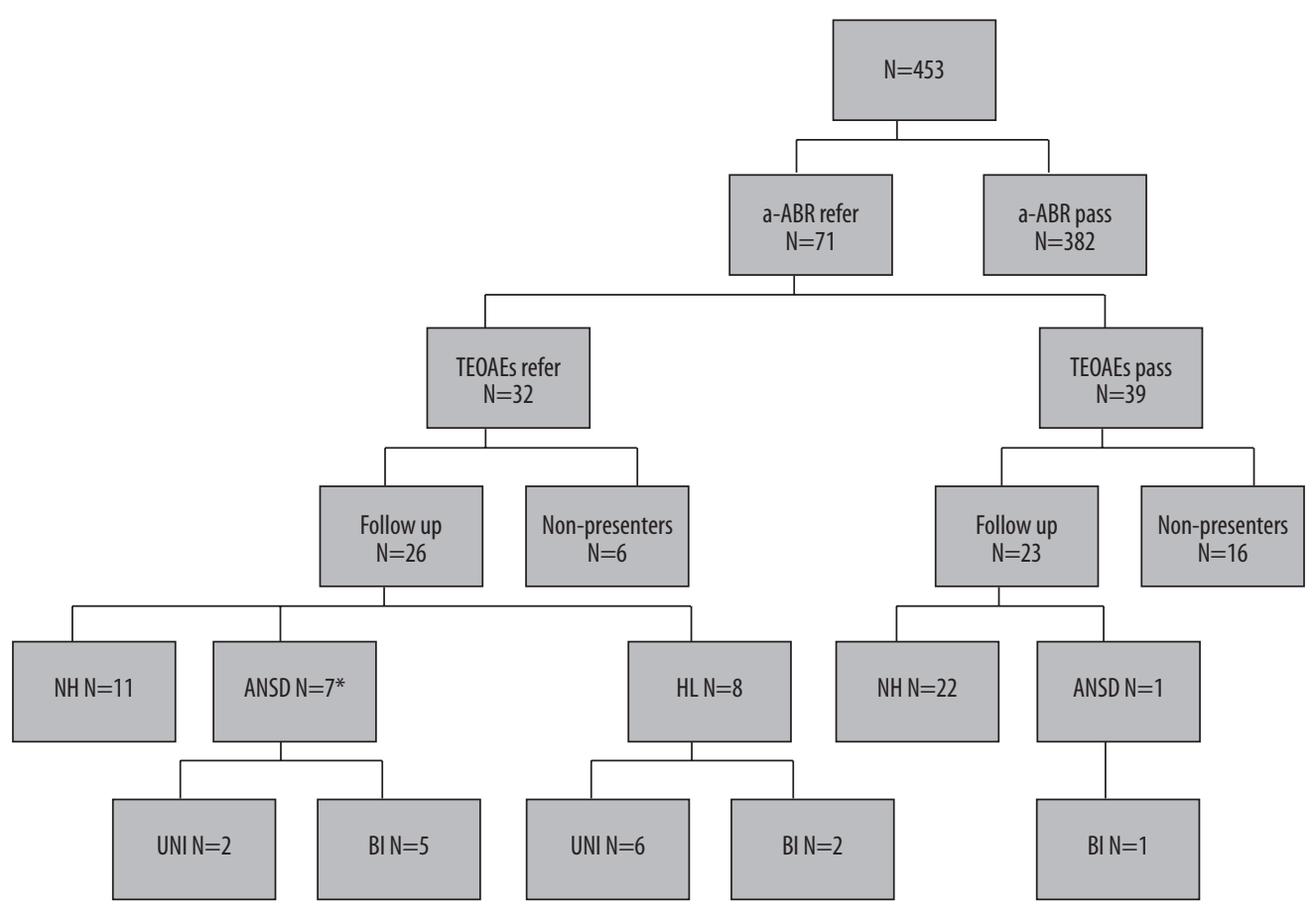

Figure 1. Outcomes of a two-step protocol hearing screening in 453 newborns admitted to the NICU. The asterisk refers to 7 newborns who, following thorough cleaning of the ear canal, eventually passed TEOAEs in the re-examination, but still failed a-ABRs and were diagnosed with possible ANSD. TEOAEs - transiently evoked otoacoustic emissions; a-ABRs - automated auditory brainstem responses; ANSD - auditory neuropathy spectrum disease; HL - hearing loss

Table 1. Prevalence of risk factors among newborns with normal and impaired hearing

\begin{tabular}{|c|c|c|c|c|c|c|c|c|c|}
\hline Risk factors & $\begin{array}{c}\text { Incidence } \\
{[\mathrm{N}=453]}\end{array}$ & & $\begin{array}{c}\mathrm{NH} \\
{[\mathrm{N}=415]}\end{array}$ & $\begin{array}{l}\text { ANSD } \\
{[\mathrm{N}=8]}\end{array}$ & $p$-value & $\begin{array}{c}\mathrm{HL} \\
{[\mathrm{N}=8]}\end{array}$ & $p$-value & $\begin{array}{c}\mathrm{HI} \\
{[\mathrm{N}=16]}\end{array}$ & $p$-value \\
\hline $\begin{array}{l}\text { Family history of childhood } \\
\text { hearing loss }\end{array}$ & $0.7 \%$ & 3 & $(0.72 \%)$ & 0 & NS & 0 & NS & 0 & NS \\
\hline Prematurity $<32$ weeks & $16.1 \%$ & 68 & $(16.46 \%)$ & 1 (12.5\%) & NS & $3(37.5 \%)$ & 0.14 & $(25 \%)$ & 0.32 \\
\hline Low birth weight $<1500 \mathrm{~g}$ & $14.1 \%$ & 55 & $(13.25 \%)$ & 1 (12.5\%) & NS & $5(62.5 \%)$ & 0.002 & 6 (37.5\%) & 0.016 \\
\hline Apgar score $\leq 6$ at 5 mins & $2.4 \%$ & 9 & $(2.17 \%)$ & 0 & NS & 0 & NS & 0 & NS \\
\hline Assisted ventilation & $14.3 \%$ & 61 & $(14.7 \%)$ & 1 (12.5\%) & NS & $3(37.5 \%)$ & 0.10 & $(25 \%)$ & 0.28 \\
\hline Medication ototoxicity & $65.1 \%$ & 269 & $(64.82 \%)$ & $5(62.5 \%)$ & 0.9 & $4 \quad(50 \%)$ & 0.46 & $9(56.3 \%)$ & 0.6 \\
\hline Hyperbilirubinemia & $11.9 \%$ & 50 & $(12.5 \%)$ & $2 \quad(25 \%)$ & 0.26 & $2 \quad(25 \%)$ & 0.26 & $(25 \%)$ & 0.13 \\
\hline In utero TORCH infection & $3.1 \%$ & 12 & $(2.89 \%)$ & $1 \quad(12.5 \%)$ & 0.22 & 1 (12.5\%) & 0.22 & $2(12.5 \%)$ & 0.05 \\
\hline Craniofacial anomalies & $2.2 \%$ & 6 & $(1.45 \%)$ & 1 (12.5\%) & 0.07 & 1 (12.5\%) & 0.07 & $2(12.5 \%)$ & 0.03 \\
\hline Syndromes & $0 \%$ & 0 & & 0 & NS & 0 & NS & 0 & NS \\
\hline Postnatal infections & $1.3 \%$ & 6 & $(1.45 \%)$ & 0 & NS & 0 & NS & 0 & NS \\
\hline Intracranial hemorrhage & $2.9 \%$ & 12 & $(2.89 \%)$ & 0 & NS & 1 (12.5\%) & 0.22 & 1 (6.25\%) & 0.4 \\
\hline Neurological disorders & $2 \%$ & 6 & $(1.45 \%)$ & 0 & NS & 1 (12.5\%) & 0.12 & $1(6.25 \%)$ & 0.23 \\
\hline
\end{tabular}

$\mathrm{NH}$ - normal hearing; ANSD - auditory neuropathy spectrum disease; $\mathrm{HL}$ - hearing loss, $\mathrm{HI}$ - hearing impairment, either ANSD or $\mathrm{HL}$.

Comparison of the incidence of risk factors between normal hearing infants and possibly hearing impaired infants clearly showed that low birth-weight (less than $1500 \mathrm{~g}$ ) was a major risk factor for hearing impairment $(p=0.016)$. Even though it was not possible to reach statistical significance regarding ANSD, in the case of newborns with possible HL, low birth-weight was reported almost 5 times more frequently than in the normal hearing population $(62.5 \%$ 


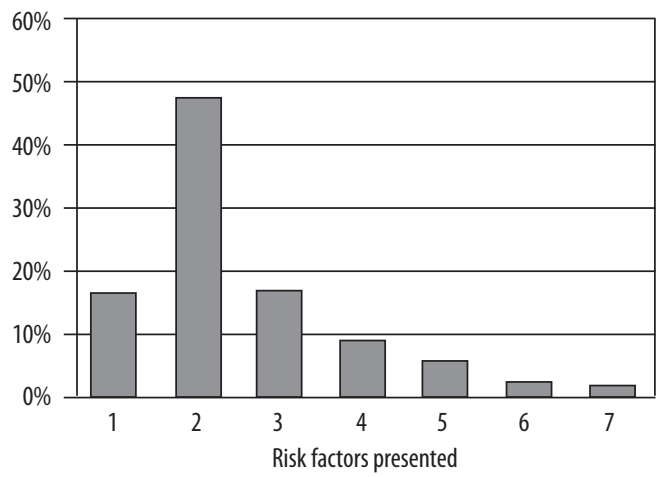

Figure 2. Co-existence of multiple risk factors

vs. $13.25 \%$ respectively), giving a strong statistically significant difference $(p=0.002)$. Low birth-weight was also the most frequently occurring risk factor $(62.5 \%)$ in the group of HL, followed by ototoxicity (50\%), whereas ototoxic medication (62.5\%) and hyperbilirubinemia (25\%) were the more prevalent in the ANSD group (Figure 3). Craniofacial abnormalities were more prevalent in the ANSD and HL groups than in normal hearing newborns $(12.5 \%$ vs. $1.45 \%$ respectively, $p=0.07)$ and had a statistically significant link to hearing impairment $(p=0.03)$. Moreover, TORCH infections, mostly CMV with a single case of congenital toxoplasmosis in our sample, seem to be related to the presence of either ANSD or HL, reaching statistical significance $(p=0.05, \mathrm{OR}=4.8)$. The analysis of frequencies for the other investigated factors resulted in no statistically significant difference between the normal hearing and hearing impaired groups, as depicted in Table 1.

Overall, 22 neonates (4.9\%) dropped out of the study before re-examination; 16 of them had passed TEOAEs (73\%) while 6 infants (27\%) had failed both a-ABRs and TEOAEs in the initial evaluation. Among them, medication ototoxicity was the most frequent risk factor (77\%) followed by low birth weight (14\%). Regarding the 49 newborns who presented for follow-up, ototoxic medication was once again the major risk factor $(75.5 \%)$ followed by prematurity and low birth-weight (27\% each) as seen in Figure 4. Prevalence analysis showed that assisted ventilation and prematurity were the only statistically significant risk factors to differ between the returns and the lost to follow-up group ( $p=0.03, p=0.05$, respectively).

\section{Discussion}

Language facilitates human communication, social interaction, and expression of ideas and emotional states. We now know it takes adequate hearing ability to develop fluent speech, but that was not always an evident fact. Until last century, poor quality spoken language was not understood to be the result of hearing impairment, and in many cases hearing aids were not prescribed to children so as to protect them from hearing their own imperfect speech [14]. Better understanding of the physiology of the auditory pathway, along with observations of the effect of hearing during critical periods on a person's ability to develop spoken language, eventually resulted in replacement of the old and deprecated term "deaf-mutism" in favour of "profound childhood deafness" [15].

Several studies over recent decades have shown that the shorter the time period without acoustic stimulation, the better the lingual, social, and emotional outcomes (provided, of course, that no other means of communication is introduced (e.g. sign language) [16]). One of the last remaining problems was that auditory responses of infants are nearly impossible to assess subjectively. It was Kemp in 1978 who introduced the electro-acoustical method of OAEs and thus provided a valuable tool in the evaluation of cochlear function [17]. In the early 1980s, pilot screening programs were conducted in the US, especially on the NICU neonates considered to be of higher risk for hearing impairment. The results showed that only $50 \%$ of hearing impaired children could be detected that way, since the other $50 \%$ presented with no obvious audiological risk factor [10]. Moreover, hearing impairment appeared to be almost 20 times more prevalent in neonates than other routinely screened diseases like phenylketonuria or sickle cell

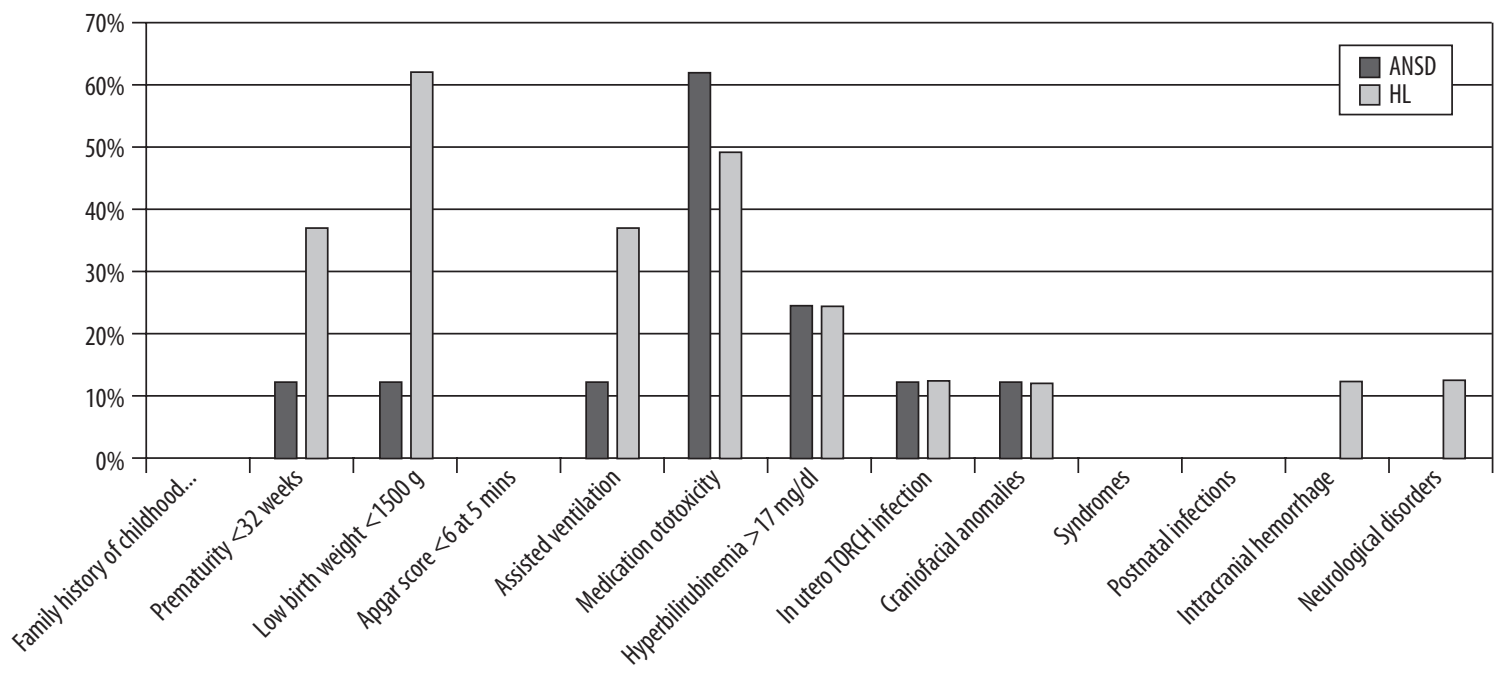

Figure 3. Frequency of risk factors in infants with possible ANSD/HL 


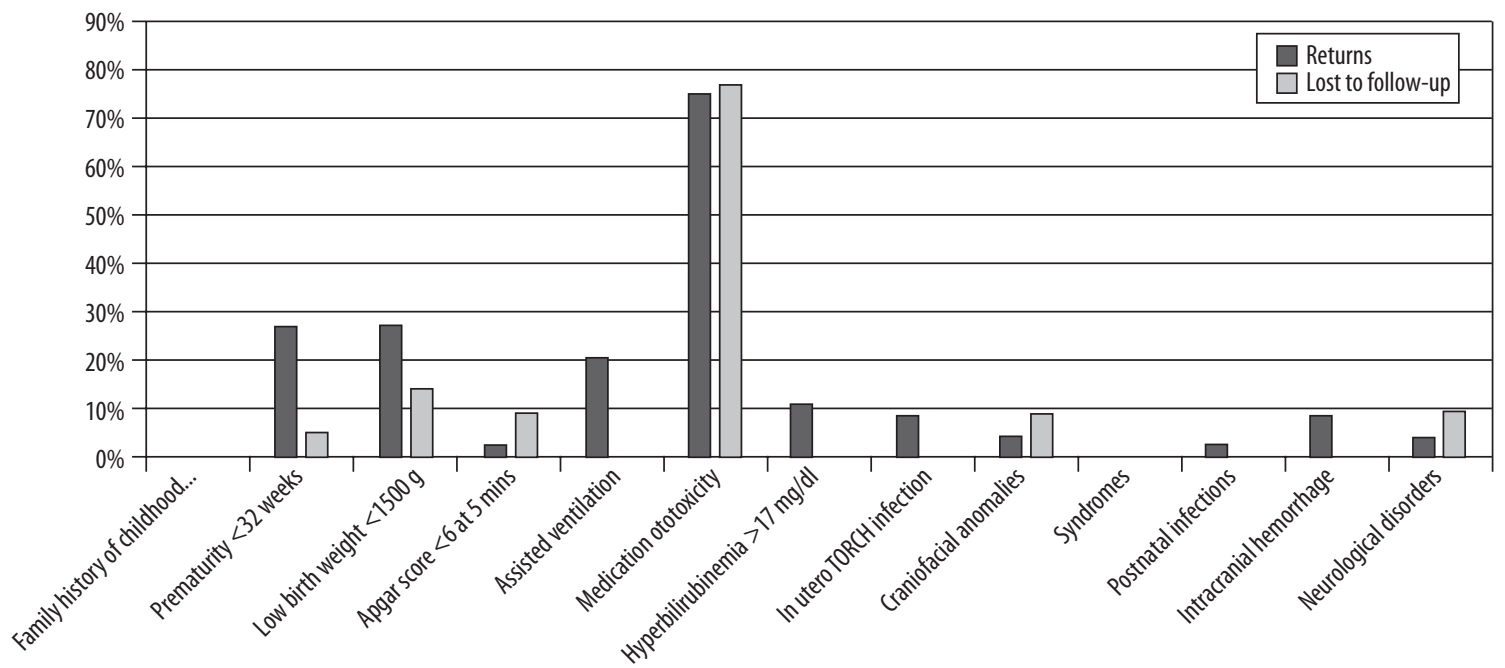

Figure 4. Prevalence of risk factors in returns and lost to follow-up neonates

anemia $[13,18]$. Therefore, in the 1990s, the Joint Committee on Infant Hearing and the American Academy of Pediatrics recommended universal newborn hearing screening as the only way to detect childhood hearing loss in a timely manner and intervene appropriately [19].

Today, OAEs and a-ABRs are the two main methods of testing the hearing ability of newborns. They are considered safe and cost-effective and provide valuable information regarding the function of the auditory pathway. The presence of normal TEOAEs indicates proper functioning of the outer hair cells of the cochlea and the absence of severe pathology in the outer and middle ear. ABRs test the overall integrity of the auditory apparatus, focusing on the synchronous retrocochlear neural activity from the inner hair cells/VIII cranial nerve to the brainstem. JCIH suggests that all full-term neonates of the well-baby nursery should be screened with OAEs and, in the case of referral, a-ABRs should be applied. As for NICU newborns, the recommendations differ and all neonates should be examined with a-ABRs in combination with OAEs (either TEOAEs or DPOAEs). The reason for the use of two different protocols is the significantly higher incidence of hearing loss as well as ANSD in NICU infants.

Auditory neuropathy spectrum disorder, also referred to as auditory neuropathy/dys-synchrony was first described by Starr et al. in 1996 and seems to be quite a common form of hearing impairment, affecting up to $10-15 \%$ of patients suffering from congenital sensorineural hearing loss [20]. In this clinical entity, the outer hair cells seem to function properly whereas there is a malfunction in subcortical afferent conduction. The site of lesion remains unclear and might be anywhere in the retrocochlear auditory pathway, from the inner hair cells and their synapses with the VIII cranial nerve to the brainstem [7]. The observed dys-synchronous neural activity results in patients with ANSD passing TEOAEs but failing ABRs. So, at least in high-risk populations like NICU newborns, OAEs are not enough and ABRs should be the basis of the screening in order not to misdiagnose ANSD cases.
In 2007, JCIH set out revised guidelines for hearing screening, with specific mention of ANSD detection and listing indicators which point to high-risk of developing permanent childhood hearing impairment [3]. Here, we have investigated the main risk factors and have tried to determine the rate at which they are linked to the presence of hearing loss or ANSD in the NICU neonates population of our hospital. Although many studies have attempted to analyze the results of hearing screening in order to optimize it, it remains the case that even though the implementation of UNHS has had a dramatic effect on early identification and timely intervention, there is still a lot to be done until the goal is reached of establishing an efficient and cost-effective hearing screening program [21].

Data analysis in our sample revealed that low birth-weight $(<1500 \mathrm{~g})$ was a major risk factor for hearing impairment. In fact, $62.5 \%$ of the infants diagnosed as having possible hearing loss presented with low birth-weight, a statistically significant difference compared to the normal hearing group. It is clear that birth weight reflects the general health status and maturity of an infant, and even though progress in NICU medical care has increased the chances of a newborn's survival, we cannot automatically assume corresponding improvement with regard to morbidity [22]. Low birth-weight has been found to be among the most frequent risk factors in several studies, but its significance is difficult to assess because in most cases it is strongly correlated with prematurity and other risk factors $[23,24]$.

In our study, craniofacial abnormalities were more frequently found in possibly hearing impaired infants than in those who eventually passed the screening. These findings correspond with the results of similar studies in which craniofacial anomalies were described as an independent risk factor for hearing loss $[25,26]$. For the ANSD and HL groups, an equal incidence of abnormalities was found $(p=0.07)$. TORCH infections are generally more prevalent in NICUs than well-baby nurseries, and are considered risk factors for the development of early or late onset hearing impairment (either ANSD or HL). Even though a strong, statistically significant relation between hearing 
deficits and intrauterine infections has been reported in several studies [27], in our analysis TORCH barely reached that level of significance $(p=0.05)$. However, the small numbers involved in the present study may have weakened the statistics.

The use of ototoxic drugs is very common in NICU daily practice, mostly due to bacterial perinatal infections and presumed sepsis. The majority of newborns in our sample, in both the normal and the impaired hearing group, had been exposed to ototoxic medication, yet no correlation of statistical significance was uncovered. This might be because of drug serum levels and the short courses of these antibiotics. Our results match those of many authors who have investigated ototoxicity, especially aminoglycosides and loop diuretics, in NICU populations: even with extended regimens and the simultaneous administration of more than one ototoxic drug, there seems to have been no increase in the incidence of hearing loss [28-30]. Nevertheless, the regular assessment of drug serum levels and short administrations are strongly recommended. In the present study, the prevalence of HL and ANSD was $1.8 \%$, while false referral rates for TEOAEs and a-ABRs were $4 \%$ and $7.3 \%$ respectively. Currently, the prevalence of sensorineural hearing loss worldwide is estimated at $2-5 \%$ when referring to NICU graduates, whereas $2-15 \%$ of infants suffering permanent hearing impairment will eventually be diagnosed with ANSD [31]. One weakness of the present study, as in many similar studies, is that the final results of the full detailed hearing evaluation are not included.

In our sample, almost one-third of the newborns referred to re-examination were lost to follow-up. This is an alarming statistic which is clearly repeated in many other studies and is one of the major drawbacks of hearing screening programs. A recent review of the literature revealed that the rate of non-presenters to re-examination can be as high as $65 \%$ [32]. Korres et al. in their study [33] made clear that retesting reduced the false positive figures but increased evasion. However, use of an efficient patient-tracking system from screening to diagnosis may produce dropout rates as low as 2\% [34]. Analysis of our data showed that newborns with high risk factors such as mechanical ventilation and prematurity were more likely to attend follow-up ( $p=0.03, p=0.05$, respectively). This outcome can be attributed to either longer admission to the NICU (so that the neonates were still in hospital at the re-examination) or to a higher level of parental vigilance when the severity of the morbidity is realised. In any case, the implementation of an efficient universal hearing screening program requires both dedicated data keepers and wellinformed caregivers.

\section{Conclusions}

ABRs and OAEs (both TEOAEs and DPOAEs) remain the cornerstones of any universal hearing screening program in neonatal intensive care units. An efficient tracking system is needed to reduce the number of neonates lost to follow-up. Low birth-weight, craniofacial deformities, and TORCH infections appear to be the most significant factors predisposing infants to hearing impairment.

\section{Acknowledgements}

We would like to thank all the NICU personnel of Attiko University Hospital for their assistance and cooperation throughout the screening program.

\section{References:}

1. Norton SJ, Gorga MP, Widen JE, Folsom RC, Sininger Y, ConeWesson $\mathrm{B}$ et al. Identification of neonatal hearing impairment: a multicenter investigation. Ear Hear, 2000; 21(5): 348-56.

2. Nikolopoulos TP. Outcomes and predictors in cochlear implantation. Doctoral Thesis. University of Nottingham, Nottingham, 2000.

3. American Academy of Pediatrics Joint Committee on Infant Hearing Year 2007 Position Statement. Principles and guidelines for early hearing detection and intervention programs. Pediatrics, 2007; 120(4): 898-921.

4. American Academy of Pediatrics Joint Committee on Infant Hearing 1994 Position Statement. Pediatrics, 1995; 95(1): $152-56$.

5. Hehar SS, Nikolopoulos TP, Gibbin KP, O’Donoghue GM. Surgery and functional outcomes in deaf children receiving cochlear implants before age 2 years. Arch Otolaryngol Head Neck Surg, 2002; 128(1): 11-14.

6. Pimperton H, Blythe H, Kreppner J, Mahon M, Peacock JL, Stevenson $\mathrm{J}$ et al. The impact of universal newborn hearing screening on long-term literacy outcomes: A prospective cohort study. Arch Dis Child, 2016; 101(1): 9-15.

7. Starr A, Picton TW, Sininger Y, Hood LJ, Berlin CI. Auditory neuropathy. Brain, 1996; 119(3): 741-53.
8. Paludetti G, Conti G, Di Nardo W, De Corso E, Rolesi R, Picciotti PM et al. Infant hearing loss: From diagnosis to therapy. Official Report of XXI Conference of Italian Society of Pediatric Otorhinolaryngology. Acta Otorhinolaryngol Ital, 2012; 32(6): 347-70.

9. ACMG. Genetics Evaluation Guidelines for the Etiologic Diagnosis of Congenital Hearing Loss. Genetic Evaluation of Congenital Hearing Loss Expert Panel. Genet Med, 2002; 4(3): $162-71$.

10. U.S. Preventive Services Task Force. Universal screening for hearing loss in newborns: recommendation statement. Am Fam Physician, 2010; 81(2): 185.

11. Bielecki I, Horbulewicz A, Wolan T. Prevalence and risk factors for auditory neuropathy spectrum disorder in a screened newborn population at risk for hearing loss. Int J Pediatr Otorhinolaryngol, 2012; 76(11): 1668-70.

12. Hille ET, van Straaten HI, Verkerk PH. Dutch NICU Neonatal Hearing Screening Working Group. Prevalence and independent risk factors for hearing loss in NICU infants. Acta Paediatr, 2007; 96(8): 1155-58.

13. Chalkiadakis V, Geramas I, Marangoudakis P, Kandiloros D, Vlastarakos P, Nikolopoulos TP. Neonatal hearing screening in intensive care units. J Hear Sci, 2014; 4(2): 9-16.

14. Ptok M. Early detection of hearing impairment in newborns and infants. Dtsch Arztebl Int, 2011; 108(25): 426-31. 
15. Fraser GR. Profound childhood deafness. J Med Genet, 1964; 1(2): 118-51.

16. Nikolopoulos TP, Gibbin KP, Dyar D. Predicting speech perception outcomes following cochlear implantation using Nottingham Children's Implant Profile (NChIP). Int J Pediatr Otorhinolaryngol, 2004; 68(2): 137-41.

17. Kemp DT. Stimulated acoustic emissions from within the human auditory system. J Acoust Soc Am, 1978; 64(5): 1386-91.

18. Mehl AL, Thomson V. Newborn hearing screening: the great omission. Pediatrics, 1998; 101(1): E4.

19. Erenberg A, Lemons J, Sia C, Trunkel D, Ziring P. Newborn and infant hearing loss: detection and intervention. American Academy of Pediatrics, Task Force on Newborn and Infant Hearing, 1998-1999. Pediatrics, 1999; 103(2): 527-30.

20. Berlin CI, Hood LJ, Morlet T, Wilensky D, Li L, Mattingly KR et al. Multi-site diagnosis and management of 260 patients with auditory neuropathy/dys-synchrony (auditory neuropathy spectrum disorder). Int J Audiol, 2010; 49(1): 30-43.

21. Nikolopoulos TP. Neonatal hearing screening: what we have achieved and what needs to be improved. Int J Pediatr Otorhinolaryngol, 2015; 79(5): 635-37.

22. Horbar JD, Carpenter JH, Badger GJ, Kenny MJ, Soll RF, Morrow KA et al. Mortality and neonatal morbidity among infants 501 to 1500 grams from 2000 to 2009. Pediatrics, 2012; 129(6): 1019-26.

23. Vohr BR, Widen JE, Cone-Wesson B, Sininger YS, Gorga MP, Folsom RC et al. Identification of neonatal hearing impairment: Characteristics of infants in the neonatal intensive care unit and well-baby nursery. Ear Hear, 2000; 21(5): 373-82.

24. Bielecki I, Horbulewicz A, Wolan T. Risk factors associated with hearing loss in infants: an analysis of 5282 referred neonates. Int J Pediatr Otorhinolaryngol, 2011; 75(7): 925-30.

25. Valkama AM, Laitakari KT, Tolonen EU, Vayrynen MR, Vainionpaa LK, Koivisto ME. Prediction of permanent hearing loss in high-risk preterm infants at term age. Eur J Pediatr, 2000; 159(6): 459-64.
26. Poonual W, Navacharoen N, Kangsanarak J, Namwongprom S. Risk factors for hearing loss in infants under universal hearing screening program in Northern Thailand. J Multidiscip Healthc, 2016; 9: 1-5.

27. Salvago P, Martines E, Martines F. Prevalence and risk factors for sensorineural hearing loss: Western Sicily overview. Eur Arch Otorhinolaryngol, 2013; 270(12): 3049-56.

28. Rais-Bahrami K, Majd M, Veszelovszky E, Short BL. Use of furosemide and hearing loss in neonatal intensive care survivors. Am J Perinatol, 2004; 21(6): 329-32.

29. El-Barbary MN, Ismail RI, Ibrahim AA. Gentamicin extended interval regimen and ototoxicity in neonates. Int J Pediatr Otorhinolaryngol, 2015; 79(8): 1294-98.

30. Yoshikawa S, Ikeda K, Kudo T, Kobayashi T. The effects of hypoxia, premature birth, infection, ototoxic drugs, circulatory system and congenital disease on neonatal hearing loss. Auris Nasus Larynx, 2004; 31(4): 361-68.

31. Walker E, McCreery R, Spratford M, Roush P. Children with auditory neuropathy spectrum disorder fitted with hearing aids applying the American Academy of Audiology Pediatric Amplification Guideline: current practice and outcomes. J Am Acad Audiol, 2016; 27(3): 204-18.

32. Papacharalampous GX, Nikolopoulos TP, Davilis DI, Xenellis IE, Korres SG. Universal newborn hearing screening, a revolutionary diagnosis of deafness: Real benefits and limitations. Eur Arch Otorhinolaryngol, 2011; 268(10): 1399-406.

33. Korres S, Nikolopoulos TP, Peraki EE, Tsiakou M, Karakitsou $\mathrm{M}$, Apostolopoulos $\mathrm{N}$ et al. Outcomes and efficacy of newborn hearing screening: Strengths and weaknesses (success or failure?). Laryngoscope, 2008; 118(7): 1253-56.

34. Holster IL, Hoeve LJ, Wieringa MH, Willis-Lorrier RM, de Gier HH. Evaluation of hearing loss after failed neonatal hearing screening. J Pediatr, 2009; 155(5): 646-50. 